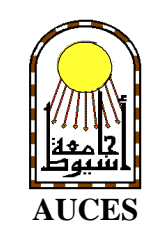

\title{
STUDIES ON THE EFFECT OF EL RAHAWAY DRAIN ON THE RIVER NILE WATER POLLUTION BY TRACE METALS AND MAJOR CATIONS AT EL-KANATER-EL KHYRIA AREA UNDER THE EFFECT OF SEASONAL VARIATION
}

\author{
M.H.Badr'; Abdelsamie Elewa ${ }^{* *}$; Mohammed B.Shehata ${ }^{* * *}$; \\ Laila Fouad Mohamed ${ }^{*}$ and Ghada S. Abdelaziz ${ }^{* *}$ \\ *Chemistry Department, Faculty of Science, Al-Azhar University for Girls. **Analytical and \\ Environment Chemistry (National Institute of Oceanography and Fishers (NIOF)
}

\begin{abstract}
:
El Rahaway drain lies at $30 \mathrm{Km}$, North to Cairo at El-Kanater El-Kahyria area, Egypt. The drain receive domestic and agriculture wastes from Giza city and pour its effluents into the Nile water of Rossetta branch. This part of the study has been performed to follow the seasonal variation of $\mathrm{pH}$; dissolved oxygen; trace metals (Fe; $\mathrm{Zn}$; $\mathrm{Cd}$; and $\mathrm{Pb}$ ) and major cation in surface and bottom water of El Rahaway drain; at the point of its discharge with the Nile water and also before and after the discharge point; and comparison with five selected locations along the River Nile at the bifurcation. This is to evaluate the effect of these effluents on the quality of the river water. The results showed that the discharged effluents decreased the $\mathrm{pH}$ by 0.5 unit, while decreased the dissolved oxygen to low values. Also high concentration values of all elements studied were observed which render the water not suitable neither for domestic use nor irrigation and expected to kill most biota in the water at the discharge point especially in autumn. This bad effect generally continue till 300 meter after the discharge point. $\mathrm{Fe}$; $\mathrm{Pb}$; and $\mathrm{Cd}$ concentration exceeds the upper limit of standard at most sites along the River Nile especially in summer. The order of the major cations was found to be: $\mathrm{Na}>\mathrm{K}>\mathrm{Mg}>\mathrm{Ca}$.

According to the calculated SAR (sodium adsorption ratios), the water quality of River Nile for irrigation was lower at many sites along the River Nile especially in summer and autumn.Generally it can be concluded that the river of Nile River is a soft water polluted with Fe; Cd and high level of $\mathrm{Pb}$.
\end{abstract}

\section{INTRODUCTION:}

$\mathrm{Fe}, \mathrm{Zn}, \mathrm{Cd}$ and $\mathrm{Pb}$ are common pollutants which are widely distributed in aquatic environment. According to United Nation Environmental Program (UNEP). the threshold toxicity values of these metals are $0.3,5.00$, $0.005,0.05 \mathrm{mg} / \mathrm{L}$ respectively. Iron is a component of iron-porphyrins haem and ferroxins (Willy, 1992), and it is essential for growth and well being of living organisms including man. However it likely to show toxic effects when organisms are exposed to levels higher than normally required, El-Sayed et al. (1998).Zinc is unusual in that it has low toxicity to man, but relatively high toxic to fish. Toxicity 
of high level zinc concentrations in man is well known,Clark et al., (1981). Cadmium has been found to be toxic to fish, and other aquatic organisms (Rao and Saxena 1981). The effects of Cd toxicity in man include many diseases, Fisher, (1987), Heinrich (1988). Lead is defined by the United State Environmental Protection Agency (USEPA) as potentially hazardous to most forms of life. It cause death of fish due to suffocation. Lead has no known beneficial biochemical attributes (Harison and de Mora 1996). Heavy metals may enter the river water from the geology of catchments soil. Probable sources included : sewage plants industrial, agriculture,domestic effluents and urban run off. Major cations $\left(\mathrm{Ca}^{2+}, \mathrm{Mg}^{2+}, \mathrm{K}^{+}\right.$, and $\left.\mathrm{Na}^{+}\right)$are naturally very variable in environmental water due to local geological climate, geographical conditions and waste water discharge. Natural concentration in fresh water for $\mathrm{Ca}$ and $\mathrm{Mg}$ are $<$ 15mg/L. But $\mathrm{K}$ concentrations are usually less than $10 \mathrm{mg} / \mathrm{L}$. Sodium is not an essential element for plant growth. On contrary, it can be toxic. In addition to damaging effect in plants, sodium can have detrimental effect on soil structure as it has a dispersion effect on soil aggregates which lead to very low infiltration of irrigation water. SAR (sodium adsorption ratio) calculation helps in estimation of the severity of $\mathrm{Na}$ concentration. The ratio can be calculated using the equation.

$$
\mathbf{S A R}=\mathrm{Na}^{+} / \sqrt{\left(\mathrm{Ca}^{2+}+\mathrm{Mg}^{2+}\right) / 2}
$$

Where $\mathrm{Na}^{+}, \mathrm{Ca}^{2+} \mathrm{Mg}^{2+}$, are the milliequivalent per liter of these elements (Richardes 1969).

The enrichment and distribution of metals in water column depends on combination of environmental, physico-chemical and biological factors, Abdel-Shafy (1981).

In last decades, the river Nile has been subjected to different sources of pollution.
Agriculture, domestic sewage and industrial effluents constitute a real threat to the River Nile, El-Matassem, (1987). Several studies on the Physico-Chemical characteristics of the River Nile water were reported by Elewa (1995,) Elewa et al. (2001), Elewa and Mahdi (1988) Mancy (1978); Saad, (1980), Abol-Atta (1978) Soltan (1988), Abdel Satar (1994), and Ghallab, (2000).

This study has been performed to follow the effect of El-Rahaway drain effluents on seasonal variation of pH: dissolved oxygen; trace metals (Fe; $\mathrm{Zn}$; $\mathrm{Cd}$; and $\mathrm{Pb}$ ) and major cations (Ca; $\mathrm{Mg}$; $\mathrm{K}$ and $\mathrm{Na}$ ) in surface and bottom water of El-Rahaway drain; at the point of discharge, and also before and after the discharge point. Comparison with five selected locations along the River Nile at bifurcation area was carried out in order to determine the effect of waste disposal discharge into the Nile water and obtain information, which may help in giving information about variability in River water quality of Delta Barrage at El-Kanater ElKahyria area in addition to its impact on biological productivity. The $\mathrm{pH}$ of a water body determines the chemical species of many metals and thereby alters the availability and toxicity in the aquatic environment DWAF (1996),also as oxidation - reduction reactions are important in natural water systems since these reactions finally affect the geochemical cycle of aqueous elements. Maria et al. (2000). This work includes also the study of the two latter parameters.

\section{Description of the area of investigation:}

The River Nile is considered as the longest River in the world, its length is approximately $6740 \mathrm{~km}$. As seen from map $I$, in the east of Africa, the blue Nile rises in the mountain of Ethiopia and joins the white Nile at Khartoum. River Nile flows northward through Egypt until it pours into Mediterranean sea by its two main 
branches namely Damietta and Rosetta. The area of investigation is $30 \mathrm{Km}$ to the North of Cairo (El-Kanater El-Kahyria area). Nine different sampling stations are chosen along the Nile branches. Map II shows the selected stations. It must be noted that, station (IV) which represents,El-Rahaway Drain, is the station which receives domestic and agriculture wastes from Al Jiza city then pour its content into the River Nile at station II. Table (1) shows the position of each station. Accordingly the sites under investigation are divided into three classes the first include station IV which is at EL-Rahaway drain itself. The second include sites I, II, III which are located before, at and after El-Rahaway drain respectively. The third class include stations V, VI, VII, VIII and IX which are located along river Nile water and don't relate to El- Rahaway station.

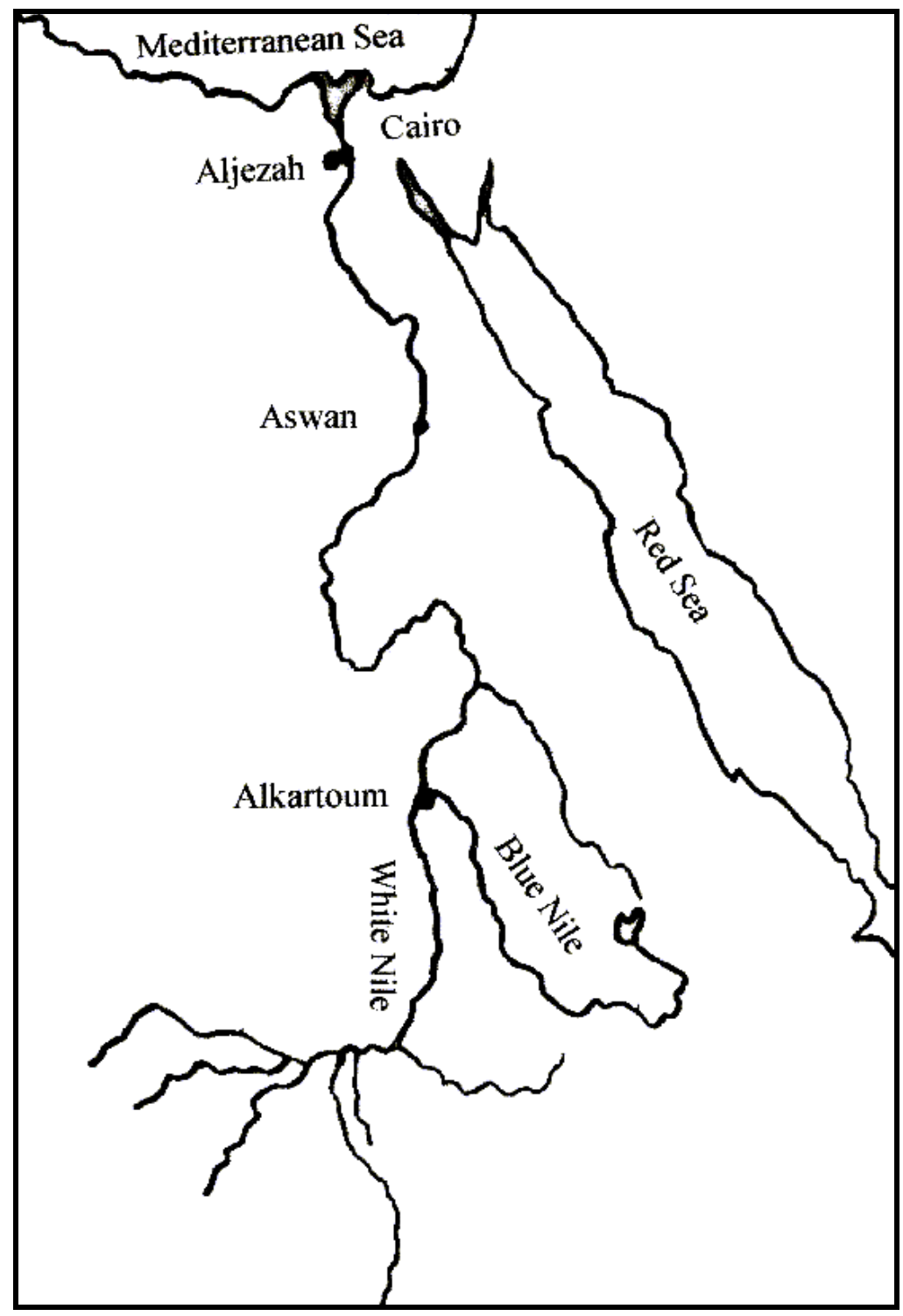

Fig. (1): Map 1, River Nile route

(Ministry of Education Book Department, Egypt) 


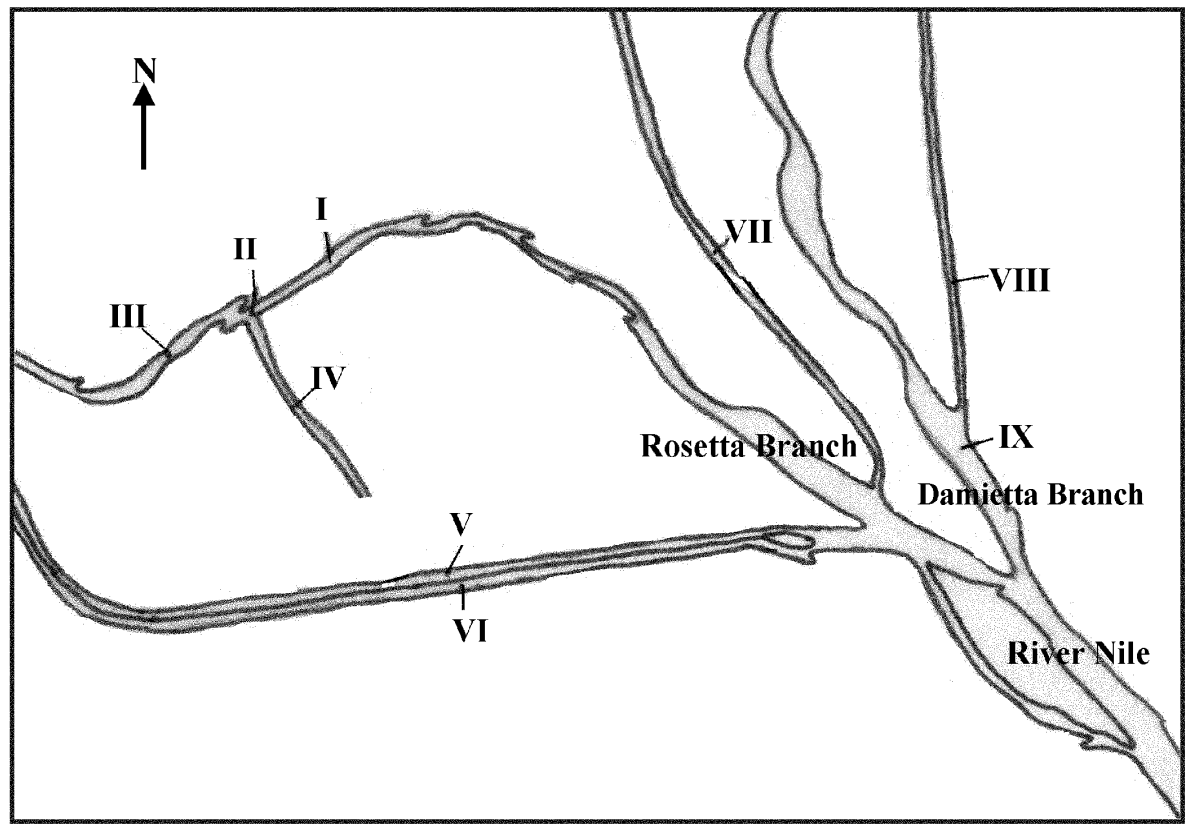

Fig. (2): Map II, showing the selected stations at the area of investigation along the River Nile at El Kanater El-Khyria region By National Institute of Oceanography and Fishers (NIOF) Egypt

Table(1): Description of selected stations

\begin{tabular}{||l|l|l||}
\hline Station & \multicolumn{1}{|c|}{ Code } & \multicolumn{1}{c|}{ Features of stations } \\
\hline Station 1 & I & 500 meter before El-Rahway drain \\
Station 2 & II & In front of El-Rahway (mixing area) \\
Station 3 & III & 300 meter after El-Rahway drain \\
Station 4 & IV & El-Rahway drain \\
Station 5 & V & El-Rayah El-Behary \\
Station 6 & VI & El-Rayah El-Nassery \\
Station 7 & VII & El-Rayah El-Menofy \\
Station 8 & VIII & El-Rayah El-Towfeky \\
Station 9 & IX & Damietta branch \\
\hline
\end{tabular}

\section{MATERIALS AND METHODS:}

Seventy two water samples were collected from the nine stations. Eighteen samples were taken per season, starting from January 2002 to December 2003. From subsurface and near bottom layers of each station two samples were taken using Van Dorn water sampler The experimental procedure of the studied parameters were carried out according to APHA (1995) as follows:

\section{1-pH measurements :}

pH was measured on the spot by using pHmeter model (Janway 3150) after buffer calibration at $\mathrm{pH} 4$ and 10.

\section{2-Dissolved Oxygen (DO):}

DO was determined by using the modified Winkler method according to APHA, (1995) and expressed as $(\mathrm{mg} / \mathrm{l})$. The method based on the addition of divalent manganese salt to the 
test water where $\mathrm{Mn}$ precipitates as $\mathrm{Mn}(\mathrm{OH})_{2}$ on addition of caustic soda solution containing KI. $\mathrm{Mn}(\mathrm{OH})_{2}$ then oxidized to higher manganese hydroxide. Then added the concentrated sulphuric acid to initiate oxidation of iodide with higher manganese hydroxide to liberate free iodine, which equivalent to dissolved oxygen then titrated against thiosulphate solution.

Water samples for DO analysis were collected in white glass stoppered bottles with fixed volume $(300 \mathrm{ml})$. The sampling was carried out in the field and carefully to avoid air bubble insert into glass bottle, then adding one $\mathrm{ml}$ of $\mathrm{MnSO}_{4}$ followed by one $\mathrm{ml}$ of alkali potassium iodide reagent just beneath the surface, stoppered the bottle and shake will by inverting it several times. Then two ml concentrated $\mathrm{H}_{2} \mathrm{SO}_{4}$ were added to dissolve the precipitation, then $100 \mathrm{ml}$ of sample is titrated against sodium thiosulphate.

The dissolved oxygen concentration expressed in $\mathrm{mg} / \mathrm{l}$ was calculated as the follow:

$\mathrm{O}_{2}(\mathrm{mg} / \mathrm{l})=\mathrm{N} \times \mathrm{V} \times 8 \times 1000 / \mathrm{ml}$ of sample.

$\mathrm{N}=$ normality of sodium thiosulphate $(0.025 \mathrm{~N})$. $\mathrm{V}=$ volume of sodium thiosulphate.

\section{3-Heavy metals:}

Four metals included $\mathrm{Fe}, \mathrm{Cu}, \mathrm{Cd}$ and $\mathrm{Pb}$ were measured in water samples using (coupled plasma 400 emission spectrometer Perkin Elemer Emission Spectrometer) according. The Preservation and digestion were carried out as follows:

Preservation: Samples were preserved immediately after collection by acidifying with concentrated $\mathrm{HNO}_{3}$ to $\mathrm{pH}<2$ by adding $5 \mathrm{ml}$ nitric acid to I liter water samples. After acidification store in refrigerator.
Digestion: Heavy metals were extracted in water samples using digestion by nitric acid method as follow:

Mix well $500 \mathrm{ml}$ of sample in a beaker at hot plate, add $10 \mathrm{ml}$ nitric acid bring slow boil, evaporate on a hot plate till volume become 200-100 ml before precipitation occurs, continue heating add another $10 \mathrm{ml}$ of nitric acid until the volume reached to $100-80 \mathrm{ml}$ until digestion is complete. The samples do not dry during digestion, mix well and complete to 100 $\mathrm{ml}$ by distilled water. and take portion of their solution for required determination. Four metals included $\mathrm{Fe}, \mathrm{Cu}, \mathrm{Cd}$ and $\mathrm{Pb}$ were determined in the digested solution using inductively coupled plasma emission spectrometry.

\section{4-Major cations:}

a-Calcium: To $25 \mathrm{ml}$ sample add $2 \mathrm{ml} \mathrm{NaOH}$ (1N) then add $0.5 \mathrm{~g}$ muroxide powder as indicator and titrate against EDTA $(0.01 M)$, where,

$\mathrm{Ca}^{++}\left(\mathrm{mgl}^{-1}\right)=\mathrm{N} \times \mathrm{V} \times 40.08 \times 1000 / \mathrm{ml}$ sample

$\mathrm{N}=$ normality of EDTA

$\mathrm{V}=$ Volume of EDTA titrant $\left(\mathrm{V}_{1}\right)$.

b-Magnesium: To $25 \mathrm{ml}$ sample add $2 \mathrm{ml}$ buffer (10) solution then add 0.5g EBT (Eriochrome Black T) as indicator then titrate against EDTA $(0.01 \mathrm{M})$, in this case the volume of EDTA equivalent to $(\mathrm{Ca}+\mathrm{Mg})$, but the volume of EDTA consumed in determination of magnesium equal to (total volume consumed in determination of (Ca+Mg)-(volume of EDTA consumed in determination of $\mathrm{Ca}$ only $\mathrm{V}_{1}$ ), so magnesium calculated as follow:

$\mathrm{Mg}^{++}\left(\mathrm{mgl}^{-1}\right)=\mathrm{N} \times \mathrm{V} \times 24.32 \times 1000 / \mathrm{ml}$ sample.

$\mathrm{N}=$ normality of EDTA.

V=Volume of EDTA used in total hardness$\left(\mathbf{V}_{1}\right)$. 
interference of $\mathrm{Fe}$ with determination of $\mathrm{Mg}$ was overcome by subtraction, while $\mathrm{Cu}$ interference was included

C-Sodium and Potassium: Sodium and potassium were determined by a Flame Photometer using calibration curve method on Jenway PSD 7 flame photometer.

\section{RESULTS AND DISCUSSION:}

Triplet analysis were carried out for each parameter and the average values were recorded. The pH of a water body according to Target water quality Range (TWQR) in water for domestic use (6 to 9) (DWAF 1996). Fig. (2) show the seasonal variation of $\mathrm{pH}$ in the river Nile water at different stations. According to these data, the pH of El-Rahaway drain (site IV) ranged from (7.30-7.33) for surface and bottom water respectively through the year. This is compared with (7.92-8.01); (7.29-7.56); (7.308.08) for surface and bottom water at sites I, II, III which are located before; at; and after the drain station respectively. For V, VI, VII, VIII and $\mathrm{XI}$ sites, The average $\mathrm{pH}$ range was7.818.28.The relatively lowest $\mathrm{pH}$ of the Nile water can be observed at sites II and III. This can be attributed to the discharge of effluents which loaded with a large amount of organic acids. It is noted that the relatively higher values can be attained as the temperature decrease, which may be attributed to the photosynthetic activity and decrease of the amount of dissolved $\mathrm{CO}_{2}$ gas in water. Abdel-Aleem and Samaan (1969), ElWakeel and Wahaby (1970).

(a)

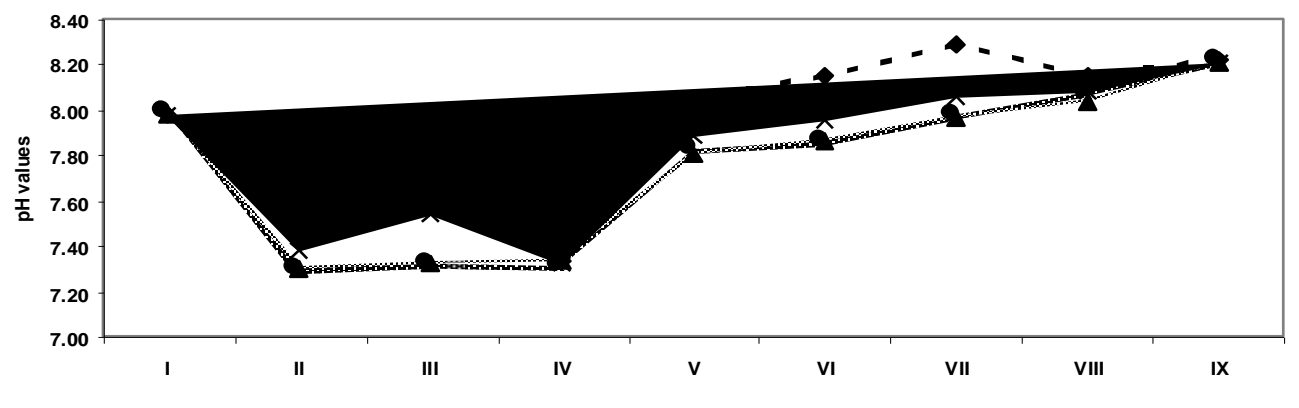

(b)

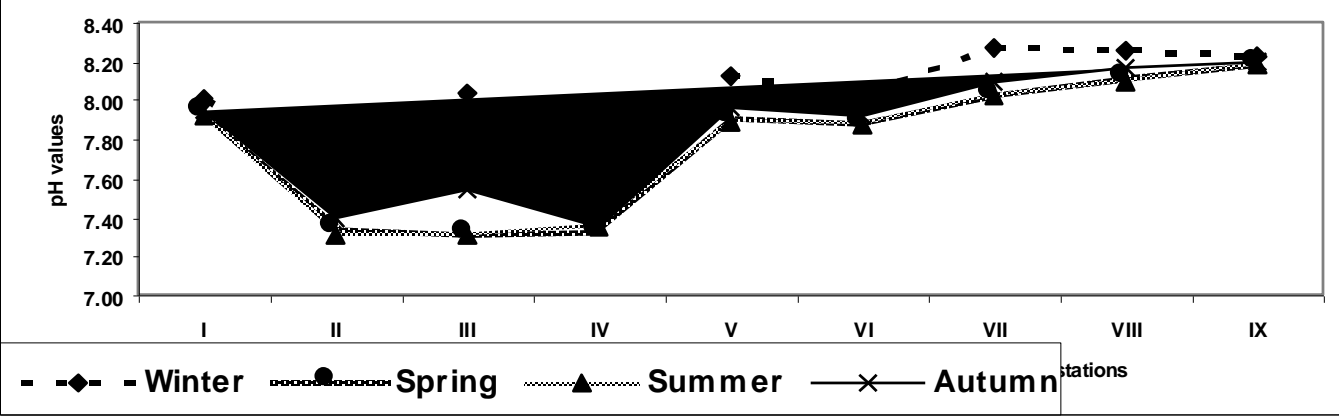

Figure (3) : Seasonal variation of pH in River Nile at El-Kanater El-Khairia area

$\begin{array}{ll}\text { (a) surface water } & \text { (b) bottom water }\end{array}$ 
Generally it can be noted that the average pH of Nile water at different location lies within the permissible range.

Dissolved Oxygen: Prolonged exposure to low dissolved oxygen level $(<5-6 \mathrm{mg} / \mathrm{L})$ will increase organisms susceptibility to other environmental stress. The exposure to $<2 \mathrm{mg} / \mathrm{L}$ (<30\% saturation) for days may kill most of biota in the aquatic system (Gower, 1980). The introduction of excess of organic matter may result in a depletion of oxygen from an aquatic system mainly during warm stagnant condition (Maria et al., 2000).
The seasonal variations of dissolved oxygen concentration in $\mathrm{mg} / \mathrm{L}$ at different sites under investigation are graphically represented in Fig. (4). According to these results, the annual average value of dissolved oxygen for surface and bottom water at El- Rahaway drain (site IV) are 0.7 and $0.5 \mathrm{mg} / \mathrm{l}$ respectively. The corresponding values for sites I, II, III are 10.3 and $9.6 ; 2.8$ and $1.5 ; 7.7$ and $7.5 \mathrm{mg} / \mathrm{l}$, which compared with $9.2-9.7 \mathrm{mg} / \mathrm{l}$ for surface water and 7.5-9.2 for bottom water for sites V, VI, VII, VIII, and XI respectively.
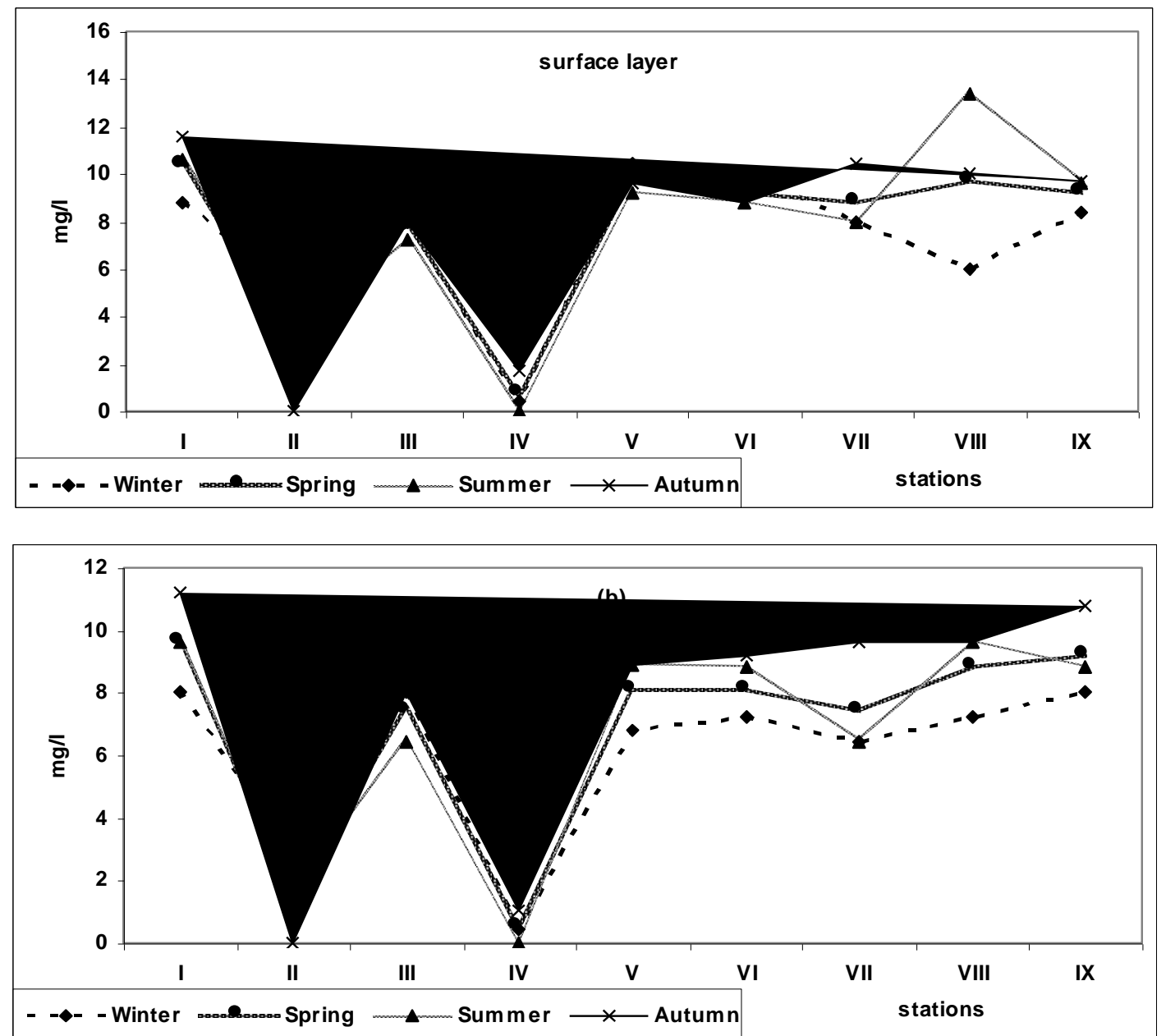

Fig. (4): Seasonal variation of dissolved oxygen concentration $\mathrm{mg} / \mathrm{L}$ in River Nile at El-Kanater El-Khyria region during 2003 (a) surface water (b) bottom water 
From these results It is observed that the high oxygen content of water at the sites $I, V$, VI, VII, VIII and XI is reduced to very low values at site II (point of discharge). This danger effect is a direct result of discharge effluents loaded with excess of organic wastes and should affect the biota at this site especially in autumn. The decrease in DO level at site III indicates that the dangerous effect of the discharge effluents into River Nile can be continued till $300 \mathrm{~m}$ after the discharge point.

The dissolved oxygen values generally showed an increase especially during autumn season at other sites, which may be attributed to activities of air movement which allowing more transfer of oxygen across the air-water interface and also is due turbulence in the flowing water (Maria et al., 2000). Relatively lower temperature in autumn may increase the ability of water to hold dissolved oxygen, Radwan et al. (2003).

It can be concluded that the DO concentration at different sites along Nile-River is greatly affected by seasonal variation but it lies within the safe level during all seasons except at El-Rahaway drain discharge point where it can be decreased to serious levels.

\section{Trace metals:}

The factors increase trace metal such as $\mathrm{Fe}, \mathrm{Zn}, \mathrm{Cd}$ and $\mathrm{Pb}$ in natural aqueous systems may be include :

-High content natural and anthropogenic organic matter which may concentrated in the surface film due to its surfactant and correlation properties and stabilize trace metals by complexation (Rashid and Leonard (1973). This may also include particulate matter (Harrison and Mora 1996).
-Decomposition and decay of phytoplankton and other aquatic plants which working as metal accumulators Harrison and De Mora(1996).

-Lower pH and high temperature increase the concentration of heavy metals in water, (Doilido and Best 1993).

-Increase of water level or mixing of wastes with water and water sediments interactions. (Harrison and De Mora, 1996)

-The ability of some metals to form very stable dissolved complexes Awofolu et al (2005) and atmospheric input Isail et al (2003) (as in case of lead).

On other hand, the factors decrease trace metals in natural aqueous systems may be include :

-Surface adsorption of metallic element by colloidal $\mathrm{Fe}_{2} \mathrm{O}_{3}$ naturally occruing in water streams (Maria et al., 2000).

-The high availability of some trace elements to uptake by phytoplankton and zooplankton and other organisms in surface water lead to decrease of their content in the surface water (Harrison and De Mora, 1996)-Also in natural water Fe undergoes oxidation- reduction reaction:

$4 \mathrm{Fe}^{2+}+\mathrm{O}_{2}+4 \mathrm{H}^{+} \rightleftharpoons 4 \mathrm{Fe}^{3+}+\mathrm{H}_{2} \mathrm{O}$

So, Fe may exist as $\mathrm{Fe}^{2+}$ or $\mathrm{Fe}^{3+}$. According to Minear and Keith (1982), both oxidation and alkalinity conditions promote precipitation of $\mathrm{Fe}$, while both reduction and acidic promote its dissolution. Iron precipitated as $\mathrm{Fe}(\mathrm{OH})_{3}$ which can adsorb many trace metals. (Maria et al., 2000).

Table (2) summarize seasonal variation of trace metal $\mathrm{Fe}$; $\mathrm{Zn}$; $\mathrm{Cd}$; and $\mathrm{Pb}$ (in $\mathrm{mg} / \mathrm{l}$ ) at different sites studied. 
Table (2) : Seasonal variation of trace metal (mg/l) in Nile water at El-Kanater -El Khyria area during 2003 in surface water (S) and bottom water (B)

\begin{tabular}{|c|c|c|c|c|c|c|c|c|c|}
\hline \multirow{2}{*}{ Season } & \multirow{2}{*}{ Site } & \multicolumn{2}{|c|}{$\overline{\mathrm{Fe}}$} & \multicolumn{2}{|c|}{$\overline{Z n}$} & \multicolumn{2}{|c|}{ Cd } & \multicolumn{2}{|c|}{$\overline{P \mathbf{P b}}$} \\
\hline & & $\mathbf{S}$ & B & $\mathbf{S}$ & B & $\mathbf{S}$ & B & $\mathbf{S}$ & B \\
\hline \multirow{7}{*}{ 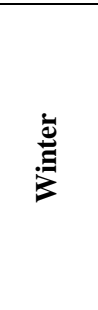 } & I & 5.07 & 0.91 & 0.088 & 0.11 & 0.003 & 0.000 & 0.291 & 0.305 \\
\hline & II & 4.49 & 1.40 & 0.099 & 0.154 & 0.021 & 0.562 & 0.310 & 0.317 \\
\hline & III & 4.27 & 1.07 & 0.055 & 0.162 & 0.005 & 0.003 & 0.209 & 0.179 \\
\hline & IV & 7.27 & 5.44 & 0.230 & 0.420 & 0.002 & 0.011 & 0.238 & 0.389 \\
\hline & $\mathbf{V}$ & 6.57 & 1.75 & 0.101 & 0.149 & 0.002 & 0.013 & 0.237 & 0.194 \\
\hline & VIII & 7.60 & 2.63 & 0.825 & 0.178 & n.d & 0.025 & 0.337 & 0.311 \\
\hline & IX & 7.07 & 2.09 & 0.553 & 0.103 & 0.005 & 0.007 & 0.382 & 0.186 \\
\hline \multirow{5}{*}{ 品 } & I & $\ldots$. & 3.41 & 0.150 & 0.160 & $\ldots$ & 0.007 & $\ldots$ & 0.152 \\
\hline & П & 7.24 & 14.47 & 0.276 & 0.460 & 0.007 & 0.008 & 0.484 & 0.174 \\
\hline & III & 6.31 & 7.71 & 0.223 & 0.324 & 0.003 & 0.065 & 0.204 & 0.404 \\
\hline & VIII & 7.49 & 1.79 & 0.142 & 0.131 & 0.022 & 0.043 & 0.179 & 0.335 \\
\hline & IX & 3.58 & 4.87 & 0.418 & 0.090 & 0.149 & 0.037 & 0.305 & 0.137 \\
\hline \multirow{9}{*}{$\stackrel{\grave{\Xi}}{\Xi}$} & I & 3.44 & 9.51 & 0.112 & 0.461 & 0.037 & 0.072 & 1.176 & 0.680 \\
\hline & П & 5.61 & 9.68 & 0.259 & 0.243 & 0.011 & 0.045 & 0.747 & 0.318 \\
\hline & III & 6.08 & 8.77 & 0.361 & 0.254 & 0.013 & 0.090 & 0.323 & 0.402 \\
\hline & IV & 4.86 & 4.75 & 0.323 & 0.168 & 0.047 & 0.023 & 0.422 & 0.552 \\
\hline & $\mathbf{V}$ & 5.41 & 2.49 & 0.169 & 0.116 & 0.023 & 0.090 & 0.334 & 0.236 \\
\hline & VI & 8.60 & 6.73 & 0.106 & 0.301 & 0.027 & 0.033 & 0.347 & 0.499 \\
\hline & VII & 4.64 & 4.95 & 0.263 & 0.292 & 0.046 & 0.169 & 0.132 & 0.613 \\
\hline & VIII & 5.45 & 0.00 & 0.115 & 0.007 & 0.072 & 0.420 & 0.242 & 0.108 \\
\hline & IX & 3.39 & 5.84 & 0.249 & 0.212 & 0.037 & 0.065 & 0.160 & 0.927 \\
\hline \multirow{2}{*}{ 志 } & VIII & 6.31 & n.d & 0.030 & n.d & 0.004 & n.d & 0.135 & 0.090 \\
\hline & IX & 2.73 & n.d. & 0.144 & n.d & 0.046 & 0.02 & 0.132 & 0.086 \\
\hline
\end{tabular}

n.d : not detected

Iron : Fig. (5) shows The seasonal variation of iron concentration in surface and bottom water at the studied sits. The results show that the "annual average" of iron (in $\mathrm{mg} / \mathrm{l}$ ) for surface and bottom water at Rahawy drain (site IV) is equal to 4.45 and 6.57 respectively. For sites I, (before Rahawy drain), II (point of discharge), III (after Rahawy drain) the corresponding values were 3.47 and 3.87 ; 6.25 and $6.39 ; 5.96$ and 4.39. This is compared with 3.93 and 2.52; 8.59 and 3.52; 5.23 and 4.99; 6.71 and 1.11 and 4.17and 3.20 for surface and bottom water of sites V, VI, VII, VIII and XI along the River Nile respectively.

These results show generally, very high $\mathrm{Fe}$ concentrations which exceeds the toxic level during all seasons except in autumn at all sites. According to the above fact, the decrease in $\mathrm{Fe}$ concentration to undetected or lower values in autumn season for both surface and bottom water at sites I, V, VI, VIII, IX along River Nile may be attributed to high values of DO which promote oxidation in the above equilibrium. So, Iron precipitated as $\mathrm{Fe}(\mathrm{OH})_{3}$. But the relative 
lower values of Iron concentration at EIRahaway drain (site IV) for both surface and bottom water may be attributed to its adsorption on large amounts of organic matter. Also according to Williams (1992), the water of El-Rahawy drain contains a large amounts of $\mathrm{H}_{2} \mathrm{~S}$ which produced by sulfate reducing bacteria and absence of oxygen. This condition promotes the precipitation of iron as iron sulphide.

The seasonal variation affect the iron distribution between surface and bottom water at all sites and this effect differs according to the site location. At site VI, the order of $\mathrm{Fe}$ concentration through surface water was: winter $>$ spring $>$ summer $>$ autumn. At site III the order is reversed to: autumn> spring> summer> winter, which indicate a change in the nature of water between the two sites. The general increase of $\mathrm{Fe}$ at the discharge point, site II relative to site $I$, before the discharge point may due to dissolution effect of water during mixing, Tomas and William (1996).
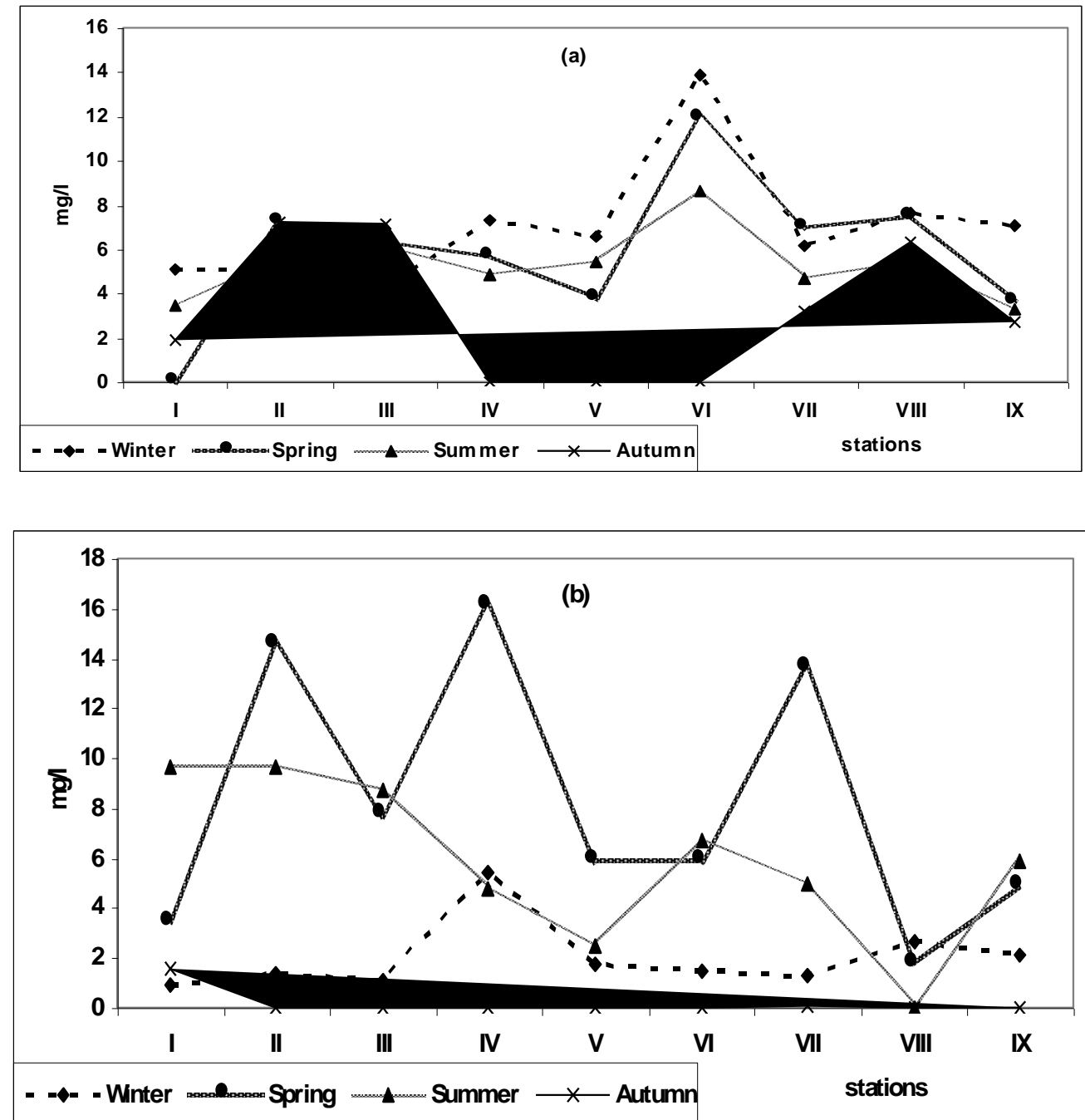

Figure (5): Seasonal variation of iron concentration (mg/l) in River Nile water at El-Kanater El-Kahyria region during 2003 (a) surface water (b) bottom water 
Zinc : Fig. (6) and Table (2) Show the seasonal variation of $\mathrm{Zn}$ concentration in $\mathrm{mg} / \mathrm{L}$ at all sites studied.

According to the results, the annual average concentration of zinc for both surface and bottom water at El- Rahaway drain (site IV) is equal to 0.170 and 0.269 respectively. For sites I, II, and III, which lies before, at and after the point of discharge of El- Rahaway drains the corresponding values were $0.175,0.381 ; 0.449$, 0.283 ; and $0.283,0.247$ respectively. This is compared with $0.083,0.140 ; 0.175,0.170 ; 0.133$, $0.186 ; 0.278,0.079$ and $0.341,0.101$ for sites $V$,
VI, VII, VIII and XI respectively along the River Nile. It is observed from the obtained data that annual average concentration of zinc generally do not reach to the toxic level in man, but exceeds the level essential to fish life $(<0.03$ 0.3/mg/l) according to Harrison and Mora (1996) at some sites. The sites which showed highest surface water contamination were VIII (El-Rahyah El-Tofeky) in winter and II (discharge point) in autumn. The highest bottom water contamination was observed at site I.
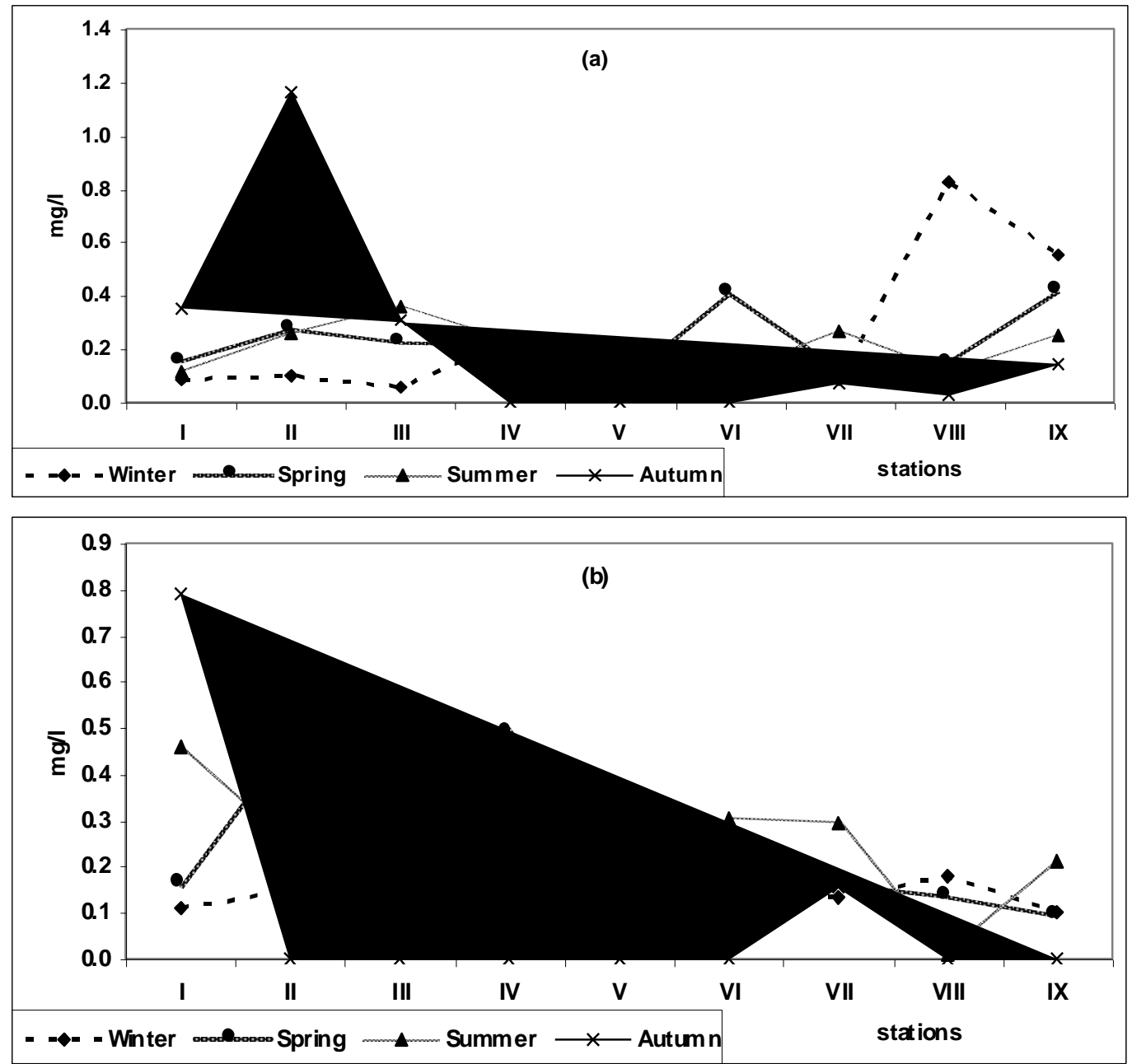

Figure (6): Seasonal variation of zinc concentration (mg/l) in River Nile at El-Kanater El-Khyria region during 2003 (a) surface water (b) bottom water 
Accordingly, it can be concluded that the pollution effect with $\mathrm{Zn}$ was observed at many studied sites and not attributed only to ElRahaway drain. It is also noted that the $\mathrm{Zn}$ concentration generally decrease in autumn for both surface and bottom water in many sites (Fig. 5) in a behavior similar to Fe see Fig. (4). This may support the explanation attributed the decrease of $\mathrm{Zn}$ concentration to its adsorption on $\mathrm{Fe}(\mathrm{OH})_{3}$ sedimentation, (Maria et al., 2000).

Cadmium: Fig. (7) and Table (2) show the seasonal variation of cadmium concentration in $\mathrm{mg} / \mathrm{L}$ at the studied sites. According to the results, Cd level exceeds the upper limit of standard at all sites but this depends strongly on the seasonal variation. The annual average of cadmium concentration in surface and bottom water at Rahaway drain station was 0.130 and 0.011 respectively. For sites I; II; and III; the corresponding values were 0.0130 and 0.021 ; 0.012 and 0.205 ; and 0.006 and 0.053 , respectively. This is compared with 0.016 and $0.045 ; 0.018$ and $0.018 ; 0.017$ and $0.057 ; 0.025$ and 0.122 and 0.059 and 0.032 for both surface and bottom of sites V; VI; VII; VIII and IX along the River water respectively. The results showed that, the cadmium in bottom water was higher than in surface water. This is may be due to:

-The tendency of cadmium to concentrate on the suspended matter (Laxen 1985)

-The mobilization of cadmium from sediment to the above water layer (Gohar, 1998).

-The high availability of cadmium uptake by phytoplankton and zooplankton and other organisms in surface water, lead to decrease of cadmium content in the surface water (Harrison and De Mora, 1996).

High level of Cd pollution was observed for surface and bottom water at site VII (EI-Rayah El-Menofy) and site VIII (El-Rayah El-
Towfeky) in summer and in surface water of site IX in spring (Damietta branch) which can not be attributed to Rahaway station but to human activities. Also, the bottom water of station II show highest cadmium contamination (0.562 $\mathrm{mg} / \mathrm{l})$ in winter. Cadmium concentration decreased to lower or undetected values at stations I, III, IV and VI for surface layer and stations V, VI and VII for bottom water in autumn.

Lead: The seasonal variation of $\mathrm{Pb}$ concentration is shown in Fig. (8) and Table (2). According to the results, the annual average of $\mathrm{Pb}$ level for surface and bottom water at Rahaway station was 0.200 and 0.308 . For sites I, II, III the corresponding values were 0.546 and $0.320 ; 0.481$ and 0.270 ; and 0.224 and 0.328 respectively. This is compared with 0.199 and $0.188 ; 0.196$ and $0.315 ; 0.256$ and $0.300 ; 0.223$ and 0.211 and 0.245 and 0.334 for surface and bottom water at sites V, VI, VII, VIII and XI, respectively.

According to these results, the level of lead is generally high. The highest level of $\mathrm{Pb}$ contamination was observed during summer for both surface and bottom water. The lowest $\mathbf{P b}$ levels were recorded during autumn which can be attributed to the formation of $\mathrm{Fe}(\mathrm{OH})_{3}$ which act as absorbent for trace element. It also noted that, the bottom water at Rahawy drain has higher $\mathrm{Pb}$ concentration at all seasons, which can also be attributed to the formation of particulates from the interaction of $\mathrm{Pb}$ with high load of organic matter Yilmazer (1999), Awofolu (2005) A very high level of Pb (1.176 $\mathrm{mg} / \mathrm{L}$ ) was recorded at position $\mathrm{I}$ in summer. According to the foregoing discussion it can be concluded that the Nile River water is polluted with $\mathrm{Cd}, \mathrm{Fe}$ and high levels of $\mathrm{Pb}$. 

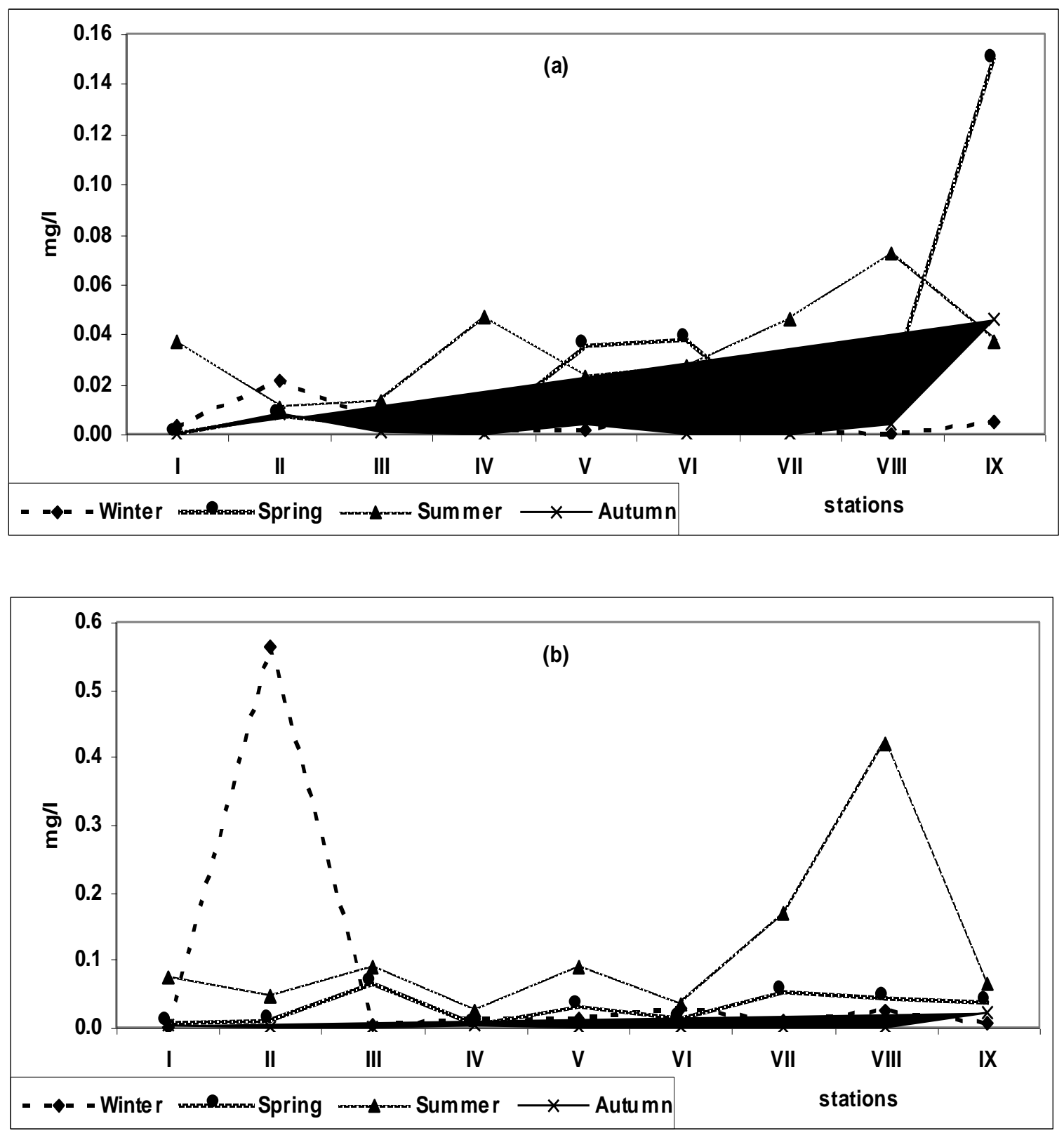

Figure (7) : Seasonal variation of cadmium concentration (mg/l) in River Nile at El-Kanater El-Kahyria region during 2003 (a) surface water (b)bottom water 

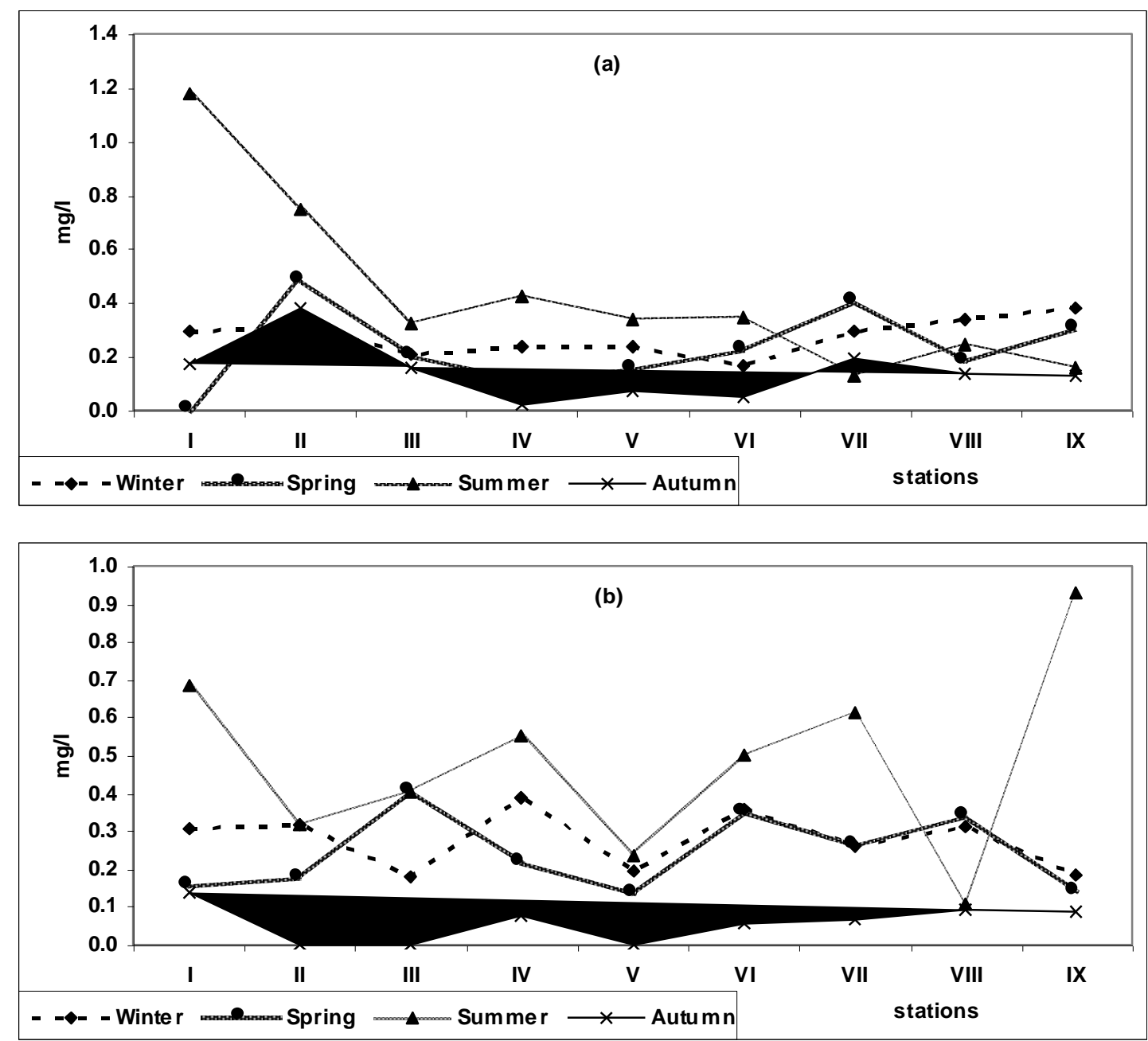

Figure (8) : Seasonal variation of lead concentration (mg/l) in River Nile at El-Kanater El -Khyria region during 2003. (a) surface water (b) bottom water

\section{Major cations:}

Table (3) Show the major cations concentrations in $(\mathrm{mg} / \mathrm{L})$ under different seasonal conditions at the sites studied with the SAR (Sodium Adsorption Ratio) and $M / D$ ratio (monovalent to divalent). Fig.(9) show the "annual average" of $\mathrm{Ca}, \mathrm{Mg}, \mathrm{Na}, \mathrm{K}$ ions under seasonal variation.

Hazards values of SAR range from a low of 5 in some fine textured soil to a high of 15 in sandier soil where rain fall is frequent (Nick 1999). The (M/D) ratio for a long time, has been considered useful for predict the phytoplankton assemblage in given water body. The $M / D$ ratio from 0.1 to 0.3 indicate dystrophy. The values below 1.0 Indicate oligotrophy and are favorable for diatoms and blue green algae. The values above 1.0 indicated eutrophy and suitable for desmids, Pearshall (1924). According to SAR results in Table (3), it is concluded that the water at the point of discharge (site II) and after $300 \mathrm{~m}$ from it at site III is not very good for irrigation during summer and autumn. It is also noted that the suitability of water for irrigation the position of IX site(at Damietta branch) far from 
El-Rahawy drain, it showed the highest SAR which indicate a lower quality of water for irrigation during summer and autumn at this site also.

On The bases of $M / D$ ratio, all sites during winter, summer, and autumn indicate eutrification. In spring all sites except for, site II and IV are oligotrophic. which can be attributed to the sewage and agriculture wastes discharged into the drain.

Table (3): Seasonal variation of average major cations concentration $(\mathrm{mg} / \mathrm{L})$ in surface and bottom River Nile water during (2003) at El-Kanater El-kahyria area

\begin{tabular}{|c|c|c|c|c|c|c|c|}
\hline Seasons & Site & $\mathbf{C a}$ & $\mathrm{Mg}$ & $\mathbf{K}$ & $\mathbf{N a}$ & SAR & M/D \\
\hline \multirow{9}{*}{ 离 } & I & 0.40 & 0.02 & 0.56 & 2.49 & 3.4 & 2.70 \\
\hline & II & 0.40 & 1.53 & 0.74 & 4.02 & 4.10 & 2.47 \\
\hline & III & 0.60 & 1.38 & 0.51 & 2.77 & 2.80 & 1.66 \\
\hline & IV & 0.46 & 1.64 & 1.14 & 6.09 & 5.9 & 3.44 \\
\hline & $\mathbf{V}$ & 0.84 & 0.95 & 0.54 & 3.26 & 3.46 & 2.12 \\
\hline & VI & 0.53 & 0.88 & 0.54 & 2.85 & 3.43 & 2.42 \\
\hline & VII & 0.34 & 1.41 & 0.51 & 2.75 & 2.9 & 1.86 \\
\hline & VIII & 0.60 & 1.05 & 0.52 & 2.78 & 3.05 & 2 \\
\hline & IX & 1.50 & 0.60 & 0.50 & 2.65 & 2.5 & 1.5 \\
\hline \multirow{9}{*}{ 惖 } & I & 0.98 & 2.63 & 0.34 & 1.34 & 0.99 & 0.45 \\
\hline & II & 0.60 & 4.16 & 0.61 & 5.75 & 3.73 & 1.3 \\
\hline & III & 0.48 & 4.81 & 0.59 & 4.25 & 2.6 & 0.92 \\
\hline & IV & 0.46 & 4.41 & 0.59 & 5.20 & 3.33 & 1.19 \\
\hline & $\mathbf{V}$ & 0.56 & 3.71 & 0.33 & 2.61 & 1.78 & 0.70 \\
\hline & VI & 0.64 & 3.13 & 0.34 & 2.55 & 1.86 & 0.77 \\
\hline & VII & 0.42 & 3.12 & 0.34 & 2.35 & 1.77 & 0.76 \\
\hline & VIII & 0.55 & 3.51 & 0.34 & 2.25 & 1.57 & 0.64 \\
\hline & IX & 0.74 & 3.76 & 0.34 & 2.58 & 1.72 & 0.66 \\
\hline \multirow{9}{*}{ 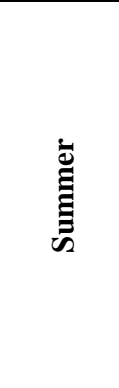 } & I & 0.70 & 1.27 & 0.43 & 5.69 & 5.70 & 3.11 \\
\hline & II & 1.20 & 1.64 & 0.64 & 10.02 & 8.42 & 3.75 \\
\hline & III & 1.24 & 1.36 & 0.65 & 11.67 & 10.24 & 4.74 \\
\hline & IV & 1.26 & 2.25 & 0.71 & 11.72 & 8.81 & 3.60 \\
\hline & $\mathbf{V}$ & 0.50 & 1.34 & 0.41 & 5.84 & 4.86 & 3.40 \\
\hline & VI & 0.60 & 1.28 & 0.40 & 5.21 & 5.37 & 2.98 \\
\hline & VII & 0.68 & 1.04 & 0.41 & 5.80 & 6.17 & 6.61 \\
\hline & VIII & 0.68 & 1.5 & 0.43 & 6.17 & 5.93 & 3.03 \\
\hline & IX & 0.80 & 1.44 & 0.45 & 6.91 & 6.5 & 3.20 \\
\hline \multirow{9}{*}{ 志 } & I & 0.24 & 2.70 & 0.35 & 7.11 & 5.88 & 2.54 \\
\hline & II & 1.06 & 2.67 & 0.73 & 14.32 & 10.45 & 4.05 \\
\hline & III & 1.20 & 2.40 & 0.67 & 13.4 & 10.00 & 3.90 \\
\hline & IV & 1.20 & 2.63 & 0.72 & 14.53 & 10.46 & 3.98 \\
\hline & $\mathbf{V}$ & 0.32 & 2.43 & 0.36 & 7.05 & 6.03 & 2.70 \\
\hline & VI & 0.44 & 2.45 & 0.44 & 6.29 & 5.20 & 2.33 \\
\hline & VII & 0.32 & 2.17 & 0.35 & 6.45 & 5.76 & 2.73 \\
\hline & VIII & 0.32 & 2.35 & 0.35 & 6.62 & 5.70 & 2.61 \\
\hline & IX & 0.48 & 2.18 & 0.35 & 6.81 & 5.90 & 2.69 \\
\hline
\end{tabular}



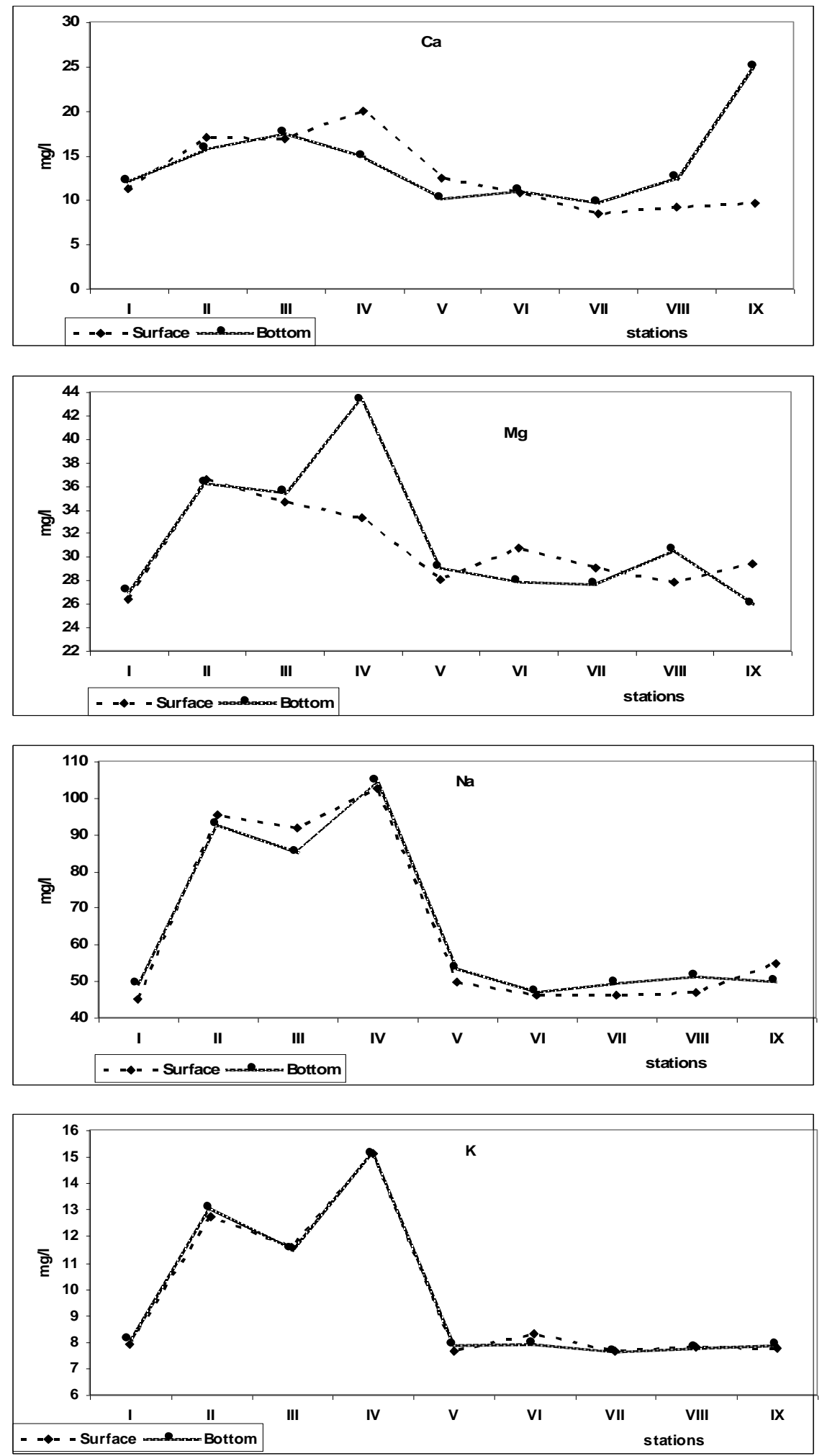

Fig. (9): The annual average concentration of the major cations at El Rahawadrain area in comparison with selected sites along River Nile at El- Kanater El Khayria area during $\mathbf{2 0 0 3}$ 


\section{REFERENCES:}

Abd-El-Aleem, A. A. and Samaan, A. A. (1969): Productivity of Lake Mariut, Egypt. I. Physical and chemical aspects. Int. Revue. ges. Hydrobiol. 54, 313-355.

Abdel-Satar, A.M. (1994): "Studies on Some Environmental Factors Affecting The distribution of Some Chemical Elements and Productivity of River Nile at ElKanater El-Khyria", M.Sc. Thesis, Faculty of Science, Cairo University, Egypt.

Abdel-Shafy I.H. (1981): Fate of trace metal in water and waste water treatment via Physicochemical techniques. Ph.D. Thesis Faculty of science Ain Shams University, Cairo, Egypt.

APHA, AWWA and WPCF (1995): Standard methods of the examination of water and waste water $16^{\text {th }}$ edn. New York.

Abou El-Atta, A.A. (1978): Egypt and Nile after High Dam. Ministry of Irrigation and Land Reclamation, Egypt. A report Jan. $145 p$.

Awofolu OR, Zambolekwa V.; Mtshemla and Fatoki OS (2005): Issn 6. 378-4738 water SA Vol. 31 No. 1

Clark B.G., Harvey D.G., and Humphrey D.J. (1981): Veterinary Toxicology $2^{\text {nd }}$ ed London, 238 pp.

Dojlido J.R. and Best G.A. (1993): Chemistry of water and water pollution Elis, Hardwood Ltd Britain.

DWAF: Department of Water Affairs and Forestry(1996): Water quality Guidelines, Pretoria.

El Motassem M. (1987): High Aswan Dam benefits and side effects. Report No. 97, High Aswan Dam. Res. Inst. Water Res. Cent Qanater, Cairo. Egypt.

El-Sayed A., Khalla F., Mansour Galal and Mohammad Athman (1998): J. Egypt
Ger. Soc. Zool. Vol. 26(B) Vertebrate Anatomy and Embryology, 39-47.

El-Wakeel S.K. and Wahby S.D. (1970): Hydrography chemistry of lake Manzalah, Egypt Arch. Hydrobiol. 67, 173-200.

Abdel-Shafy I.H. (1981): Fat of trace metal in water and waste water treatment via Physicochemical techniques. Ph.D. Thesis Faculty of science Ain Shams University, Cairo, Egypt.

Elewa, A.A. (1995): Distribution of $\mathrm{Mn}, \mathrm{Cu}, \mathrm{Zn}$, and $\mathrm{Cd}$ in water and sediment of River Nile at Aswan, Egypt. J. Appl. Sci, 8 (2): 711-713.

Elewa, A.A.; Shehata, M.B. and Abdo, M.H. (2001): Effect of thermal pollution of Shoubra El-Kheima Electric Station on the River Nile water quality. The Second International Conference and Exhibition for Life and Environment. 3-5, April, 2001.

Elewa, A.A. and Mahdi, H. (1988): Some Limnological studies on the Nile water at Cairo. Egypt. Bull. Nat. Inst. Oceanographic. \& Fish, A.R.E., 14 (2): 141-152.

Fisher A.B. (1987): Mutagenic effect of cadmium alone and in combination with ant mutagenic selenite proc. $6^{\text {th }}$ conf. on Heavy metals Environment. Newor-leans, Vol.2, CEP consultant Ltd. Edinburgh 112-114.

Ghallab, M.H.M. (2000): Some physical and chemical changes on River Nile down stream of Delta Barrage at El-Rahawy drain. M. Sc. Thesis Fac. of Sci. Ain Shams Univ. Cairo, Egypt.

Gohar M.A. (1998): Factors affecting the precipitation and dissolution of some chemical elements in River Nile at Damietta branch. M.Sc. Thesis fact. of Sci. Menofia Univ. Egypt. 
Gower, A.M. (1980): Water quality in catchments Ecosystems, John Wiley \& Sons, New York.

Harrison M.R. and De Mora J.D. (1996): Introductory chemistry for environmental science Cambridge University, Press P. 301.

Heinrich V (1988): In Hutzinger O and Sage SH (eds) Environmental Toxins, Vol. 2. Cadmium 13-15.

Herbert F.L. (1971): Industrial pollution control handbook part (2).

Isail J; Yuke and Host. (2003) Diffuse pollution conference Dublin Poster Paper.

Laxen D.P. H. (1985): Trace metal adsorption co-precipitation on hydrous ferric under realistic conditions. The role of humic substances water 19, 1229-1236.

Maria Adelaid RV Veado, Arno Hde Oliveria, Gilles Revel, Guy Pinte, Sophse Aytsult and Pierre toulhoat (2000): study of water and sediment interactions in the Das velhas River, Brazil-Major and trace elements" ISSN 0378-4738=water SA Vol. 25 No. 2, p 255-274. Available on website http://www were org.

Mancy, K.H. (1978): The environmental impacts of Aswan High Dam. A contribution from the River Nile and Lake Nasser Research Project, the Egyptian Academy Scientific Research and Technology, Cairo.

Minear R. A. and Keith L.H. (1982): Water Analysis, Vol. 2: Inorganic species, part 1 Academic press, New York.

Nick Christians (1999): GCM June 1999 Research "why injection of acid into irrigation water" Ph.D.

Pearshall W.H (1924): Phytoplankton and environment in English lake district
Review Algdigique 1:54-67 quoted by shoesnithe and Brooke (1983).

Radwan M. Williams, P. El-Sadek A. And Barcament J. (2003): Modeling of dissolved oxygen and biochemical oxygen demand in River Water using detailed and simplified models. Int. J. River Basin Management vol. 1, No. 2 97-103.

Rashid M.A. and Leonard J.D. (1973): Modification in solubility and precipitation behavior of various metals as a result of their interaction with sedimentary humic acid "chem. Geol. 11, 98-97.

Richards L.A (ed) (1965): "Diagnosis and improvement of saline and alkali soil" VSDA Agriculture office Washington D.C.

Rao I.D. and Saxena A.B (1981): Acute Toxicity of mercury, Zinc, lead, cadmium, manganese to Chironomus Sp. Int. J., Environ. Studies 16, 225-226Richard's L.A. (ed). (1969): "Diagnosis and improvement of saline and alkali soil VSDA agriculture office Washington D.C.

Soltan, M.E. (1988): Study of River Nile water pollution. M.Sc. Thesis, Fac. Sci. Aswan, South Valley University, Egypt.

Thomas G. Spiro and William M. Strgliani (ed) (1996): "chemistry of the environment" Newjercy.

Williams, T.M. (1992): Envir. Geol. Wal. Sci Vol. 20, 117-124.

Willy, J. Masschelein (1992): Unit process in drinking water treatment. Marcel Dekker p15.

Yilmazer D. (1999): Tr. Of Engineering and Environmental Sci. 23, 59-61. 
تعيين بعض العناصر الثقيلة والكاتيونات الرئيسة في مياه نهر النيل تحت تأثير التغير

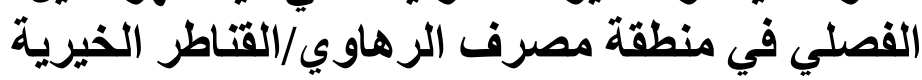

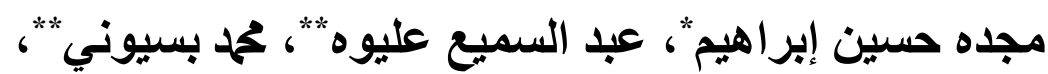

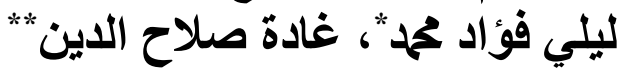

"قسم الكيمياء - كلية علوم - جامعة الأزهر (بنات)، **"المعه القومي لعلوم البحار والمصايد

تقع محطة مصرف الرهاوي على بعد · r كم شمال مدينة القاهرة في منطقة مدينة القناطر الخيرية/مصر حيث

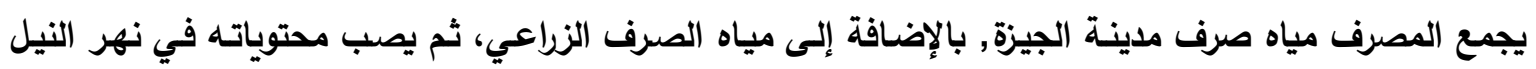
مباشرة بعد الخلط .

تهـف هذه الدراسـة إلى متابعـة تعيين الأس الهيدروجيني، الأكسجين الذائب، المعادن الثقيلة، والكاتيونـات

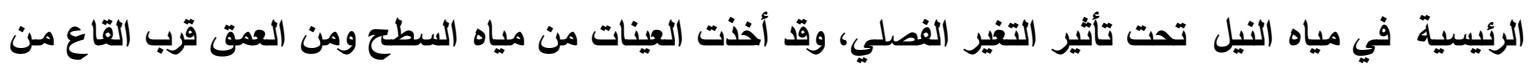

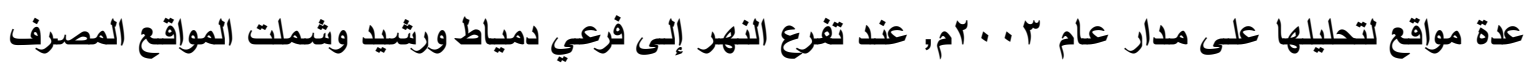

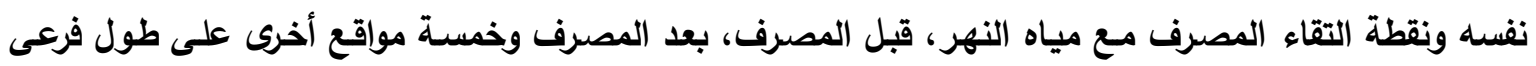
النيل في منطقة القناطر الخيرية.

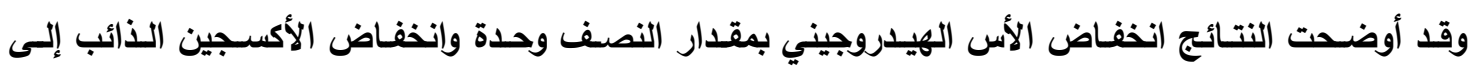
مستويات منخفضـة جدا، كذلك ارتفاع تركيز العناصر المشـار إليها إلى مستويات مرتفعسه عند التقاء مخلفـات

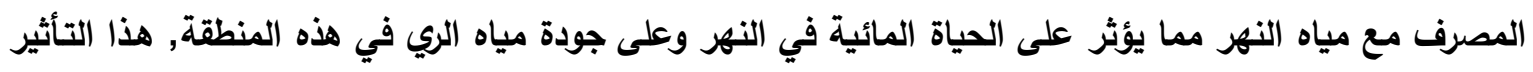

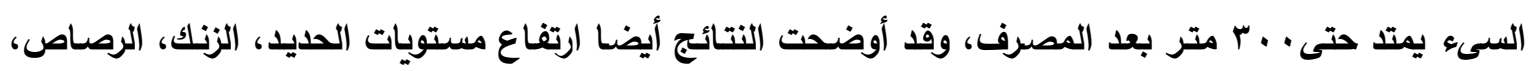

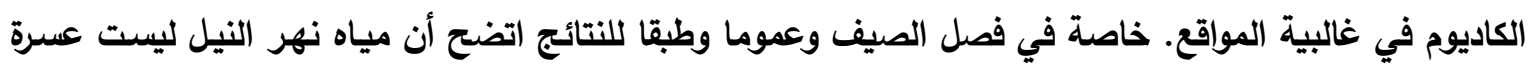
ولكنها ملوثه بالكاديوم والرصاص والحديد وتحتوي على نسب عالية من فن الصوديوم مما يؤثر على جودتها للري خاصة في فصل الخريف والصيف. 